\title{
Microbial Community, Biomass and Physico- Chemical Properties of Soil in dry tropics
}

Weldesemayat Gorems Woldemariam ( $\nabla$ c.weldesemayat@gmail.com ) Hawassa University

Nandita Ghoshal

Banaras Hindu University

Original article

Keywords: Microbial soil diversity, Land use type, Microbial biomass, Soil Physico-chemical properties

Posted Date: August 12th, 2020

DOI: https://doi.org/10.21203/rs.3.rs-36821/v1

License: (9) This work is licensed under a Creative Commons Attribution 4.0 International License. Read Full License 


\title{
Microbial Community, Biomass and Physico-Chemical Properties of Soil in Dry Tropics
}

\author{
Weldesemayat Gorems ${ }^{1 *}$ and Nandita Ghoshal ${ }^{2}$ \\ 1. Department of Wildlife and Protected Area Management, Wondo Genet College of Forestry and \\ Natural Resource, Hawassa University, P.O. Box 128, Shashemene, Ethiopia \\ *Correspondence: $\underline{\text { c.weldesemayat@gmail.com }}$ \\ 2. Centre of Advanced Study in Botany, Department of Botany, Institute of Science, Banaras Hindu \\ University, Varanasi-221005 (U.P.) India \\ Email: n_ghoshal@yahoo.co.in
}

\begin{abstract}
Soil physicochemical and microbial properties can be regarded as an important tool to assess soil quality and health. Studying the soil properties under different land use types is great practical significant for land use and soil management regarding soil carbon dynamics and climate change mitigation. However, the changes in land-use types and their effects on soil physicochemical and microbial properties are largely debated and rather unclear. Four different land use types were used to study soil microbial and soil physico-chemical properties. Soil organic carbon and total nitrogen, soil microbial biomass and microbial diversity were determined by micro kjeldahl method, fumigation and extraction method and FAME GCMs, respectively. Among all land use pattern the highest water holding capacity $(40.06 \pm 0.74 \%)$, porosity $(0.539 \pm 0.011 \%)$, soil macro-aggregates $(64.16 \pm 2.64 \%)$, organic carbon $(0.84 \pm 0.054 \%)$, total nitrogen $(0.123 \pm 0.013 \%)$, microbial biomass carbon $(570.65 \pm 35.05 \mu \mathrm{g} / \mathrm{g})$ and nitrogen $(84.21 \pm 3.186 \mu \mathrm{g} / \mathrm{g})$, basal respiration $(3.64 \pm 0.064 \mu \mathrm{g} / \mathrm{g})$ and $b$-glucosidase $(809.68 \pm 39.7 \mu \mathrm{g} \mu \mathrm{g}$ PNP g-1 dry soil h-1) were found to be under natural forest followed by in decreasing order bamboo plantation, degraded forest and agricultural land. Significant differences were observed among the land use types with microbial biomass carbon and B-glucosidase activity. Furthermore, the correlation of analysis showed that microbial biomass, organic carbon, b-glucosidas activity, total nitrogen, moisture content, porosity, water holding capacity, soil macro aggregates were positively correlated to each other and negatively correlated with bulk density, meso and micro soil aggregates at $\mathrm{p}<0.05$. The PLFA analysis showed that microbial community diversity exhibited distinct patterns among land-use types. The conversions of natural forest to other land use type, the amount of PLFA were reduced significantly. The natural forest had high microbial diversity followed by in decreasing order bamboo plantation, degraded forest and agricultural land. Among the organisms $\mathrm{G}^{-}$bacteria and fungi were showed decreasing order from natural forest, bamboo plantation, degraded forest and agricultural land. The reverse was true for G+ bacteria. The result of this study showed that soil physico-chemical and microbial properties were significantly affected by land use types. Thus bamboo based fallow has the potential for improving soil quality and properties in the short term.
\end{abstract}

Keywords: Microbial soil diversity, Land use type, Microbial biomass, Soil Physico-chemical properties 


\section{Background}

Soil microorganisms are important components of terrestrial ecosystems (Chandra et al., 2016) and drive many soil services such as nutrient cycles (Yin et al., 2010; Kirk et al., 2004 and Garbeva et al., 2004) and maintenance of soil function which directly involve in maintaining soil fertility and its structure (Kujur and Patel et al., 2014). They are also involved in mediating global climate change, by acting as $\mathrm{C}$ sources and sinks, and by generation of greenhouse gases such as nitrogen oxides and methane. Different studies have demonstrated that the soil microbial activity, biomass, and composition depend on plant type, parent material and agricultural practices. As an important part of soil ecosystem, land use changes strongly impact soil functions, particularly microbial biomass and activity, microbial community, soil organic carbon and nitrogen and other soil physical properties (Tripathy and Singh, 2009). Maintaining soil quality (which includes various soil biological, physical and chemical properties) is of major importance for any soil management strategy.

Conversion of natural forest to other land-use types leads to not only climate change, loss of biodiversity, change in ecosystem services etc, but also affects soil biological and physicochemical properties (Tilman, 2001; Ashagrie et al., 2007). Several studies have documented that the conversion of natural forest to other land-use types significantly influenced soil health and quality (Yu et al., 2012 and Kumar and Ghoshal, 2017), particularly in temperate regions (Kumar and Ghoshal, 2017). However, restoration of forests poses a major challenge globally, particularly in the tropics, as the forests in these regions are more vulnerable to land-use change (Kumer and Ghoshal., 2017 and Jackson et al., 2007). Therefore, how land-use change affects the community composition in terms of disturbance and ecosystem restoration in the dry tropics yet not clearly studied (Kumer and Ghoshal., 2017).

Increasing evidence has shown that soil microbial attributes are potential early indicators of the changes in soil quality because these parameters are more sensitive than are the chemical and physical properties of soil. The microbial biomass has been characterized as a sensitive index for changes in the soil organic carbon that result from management and land use. Hence, microbial community structure, biomass, and specific functions of soil microorganisms appear to be of major importance for general soil functions and if detectable could serve as sensitive soil quality indicators (Jenkinson \& Ladd, 1981). Therefore, the present study aims to investigate the effect of different land use types (Natural forest, Degraded forest, Bamboo plantation and Agricultural land) on the microbial community and other physic-chemical properties of soil. The study hypothesized that different land use types significantly affect the microbial community and physico-chemical properties.

\section{Results}

\section{Soil Physico-chemical properties}


Soil physico-chemical properties differed significantly under four land-use patterns (Table 1 and Figure 2). Soil porosity (0.539\%), soil aggregates and water holding capacity (WHC) (40.06\%) significantly higher in natural forest. However, soil moisture content and bulk density were significantly higher in bamboo planation $(2.78 \%)$ and agricultural land $\left(1.37 \mathrm{~g} / \mathrm{cm}^{3}\right)$, respectively at $\mathrm{p}<0.05$ (Fig 2). Soil aggregates, including macro-aggregates, meso-aggregates and microaggregates were significantly affected by land use types. Across different land use types, macroaggregates constituted (42-64\%) of total soil followed by meso-aggregates (25 to $33.6 \%$ ) and micro-aggregates (10-20\%) (Table 2). Macro-aggregates were significantly higher in natural forest $(64.16 \%)$ followed by bamboo plantation $(51.65 \%)$, degraded forest $(46.83 \%)$ and agricultural land $(42.94 \%)$. The soil organic carbon and total nitrogen ranged from $(0.435 \%$ $0.84 \%)$ and $(0.123 \%-0.014 \%)$, respectively. The \%OC and $\mathrm{tN}$ were found to be the highest in natural forest, followed by bamboo plantation and the lowest in agricultural land (Table 2). The highest \%OC value $(0.84 \%)$ and $\mathrm{tN}(0.123 \%)$ were found in natural forest soil and the lowest $\% \mathrm{OC}(0.435 \%)$ and $\mathrm{tN}(0.014 \%)$ in the agricultural land. The analysis of variance showed that there was significant difference between natural forest and other land use types at $\mathrm{P}<0.05$ in soil total nitrogen.

90

91

92

93

94

95

96

97

98

99

100

101

102

103

104

105

106

107

108

109

110

111

\section{Soil Microbial Biomass, Basal Respiration (BR) and Enzyme Activity}

As shown in Table 2, results of the MBC and MBN, BR and enzyme activity varied significantly among the land use patterns. The highest $\mathbf{M B C}$ and $\mathbf{M B N}$ were obtained from natural forest; whereas the least was recorded in agricultural land. The mean values for MBC were 570.65, 233.94, 479.03 and $225.59 \mu \mathrm{g} / \mathrm{g}$ in the natural forest, bamboo plantation degraded forest and agricultural land, respectively. Likewise, the mean MBN values under the natural forest, bamboo plantation degraded forest and agricultural soils were 84.21, 48.95, 63.05 and $43.14 \mu \mathrm{g} / \mathrm{g}$, respectively. The maximum BR was found in natural forest, and decreased substantially in bamboo plantation, degraded forest, and attained its minimum in the agricultural land (3.64,

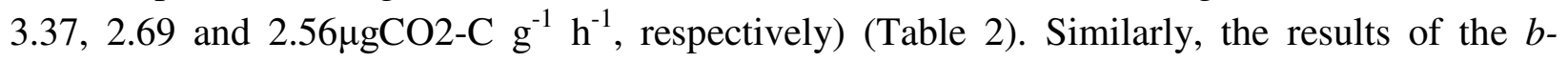
glucosidase activity varied significantly among the land uses and the activity was ranged from 380.5 to $809.69 \mu \mathrm{g}$ PNP g ${ }^{-1}$ dry soil $\mathrm{h}^{-1}$. Natural forest has shown maximum $b$-glucosidase activity (805.69) whereas degraded forest has shown the least $b$-glucosidase enzyme activity (380.8). The natural forest had $35.82 \%$ of enzyme activity followed by bamboo plantation (25.54\%), agricultural land (21.81\%) and finally the degraded forest $(16.83 \%)$.

Pearson's correlation coefficients between MBC, SOC, MBN, b-glucosidase activity, STN, moisture content, porosity, WHC, soil aggregates and bulk densityis given in Table 3. MBC, SOC, MBN, b-glucosides activity, STN and soil macro aggregates were strongly positively correlated to each other, and negatively correlated with bulk density, meso and micro soil aggregates. Additionally, soil organic carbon and total nitrogen were positively correlated with porosity ( $\mathrm{r}=0.703$ and 0.555$)$, water holding capacity ( $\mathrm{r}=0.76$ and 0.66$)$ and macro soil aggregates ( $\mathrm{r}=0.929$ and 0.970$)$ while less/weakly correlated with moisture content $(\mathrm{r}=0.548$ and 
112 0.01). In contrast, soil organic carbon and nitrogen negatively correlated with bulk density ( $\mathrm{r}=-$ 1130.722 , and $-0.568, \mathrm{p}<0.05$, respectively), soil meso ( $\mathrm{r}=-0.901,-0.989$, respectively) and micro 114 aggregates $(r=-0.946$ and $-.936, p<0.05$, respectively). Macro soil aggregates was found to be significantly positively correlated with soil total nitrogen $(r=0.97, p<0.05)$. Moreover, MBC, MBN and b-glucosidase were strongly correlated with each other.

117 In comparison to physical variables, strong and significant correlations were found between

118

119

120

121

122

123

124

125

126

127

128

129

130

131

132

133

134

135

136

137

138

139

140

141

142

143

144

145

146

147 chemical and biological variables. Microbial biomass carbon and nitrogen, b-glucosidase, showed strong positive correlation with $\mathrm{SOC}$, soil $\mathrm{tN}$ and macro soil aggregate; weakly correlated to porosity, WHC and moisture contents. However, they were negatively correlated with bulk density, soil meso and micro aggregates.

\section{Soil microbial PLFA profiles}

Results of the soil microbial PLFAs from different land use types are presented in (Table 4). The bacterial PLFAs and fungal PLFAs were significantly higher in natural forest and bamboo plantation than in degraded forest and agricultural land. The highest total bacterial and fungal PLFAs were recorded in forest soils with a dominance of G- PLFAs over the corresponding $\mathrm{G}^{+}$ PLFAs (G+/G-PLFA ratio of 0.42). However, the smallest amount of total bacterial and fungal PLFAs was recorded in agricultural land. The conversation of natural forest to bamboo plantation, degraded forest and agricultural land resulted in a significant increase in $\mathrm{G}^{+} \mathrm{PLFAs}$, however, sharp decreased in $\mathrm{G}^{-}$PLFAs and fungal PLFAs. The F: B ratios were significantly higher in natural forest soil and bamboo plantation soils than degraded forest and agricultural land (Table 4).

\section{Discussion}

This study demonstrated that land use change greatly impacted soil microbial community and biomass, basal microbial respiration as well as soil physic-chemical properties in the dry tropics of India (Figure 2, and Tables 1, 2, 3 and 4). Land use change may lead to changes in soil physico-chemical and biological properties through their influence on various ecological processes (Chen et al., 2010 and Zhang et al., 2016). The conversion of native ecosystem to other land use types like agricultural land caused a negative response in soil physico-chemical and microbial properties in the study area. Generally, natural forest found to be significantly higher in porosity, macro-aggregates, WHC but the least in bulk density, meso-aggregates and micro soil aggregates whereas agricultural land found to be the higher in bulk density (Fig. $2 \&$ Table 1). Similar study reported by Tripathi and Singh (2007) soil physic-chemical properties can be significantly improved for the vegetation systems having higher organic matter content such as forest, mixed forest ecosystems compared to savanna and cropland ecosystems. 
The reduction in WHC, porosity, moisture content and macro aggregates, and increase in bulk density due to the conversion of natural forest to degraded forest and agricultural land (Fig 1). Such trends were also reported by Singh et al. (2009) and Chen et al. (2010). This was probably due to the decrease in organic matter and aeration following cultivation, which may promote drying (Singh et al, 2009); evaporation in the soil surface Singh et al, (2009); decreased SOC and soil aggregation (Iqbal and Goni, 2015), as a result of repeated events of sowing and harvesting. Bot and Benites (2005) also reported that bulk density was lower in soils with high organic matter content. The present study revealed that re-afforestation of the degraded forest significantly improves the soil physical properties. Bamboo planation were significantly increased the WHC, porosity, moisture content and macro aggregates, but decreased in bulk density of soil as compared to degraded forest and agricultural land (Fig 1). This is probably due to higher addition of leaf and root litter in the soil (Zhang et al., 1988 and Singh et al., 1989). the higher soil aggregates in natural forest could be due to the fact that no tillage in natural forest, lower disturbance and higher organic matter input (litters and root exudates) that bind soil aggregates together resulting in improved soil structure formation (Bot and Benites, 2005).

Soil organic $\mathrm{C}$ and $\mathrm{N}$ is considered to be one of the major attributes of soil fertility and agricultural sustainability (Lal, 2002). As per the finding of this study, the highest $\mathrm{OC}$ and $\mathrm{tN}$ was found to be under natural forest $(0.84 \%, 0.123 \%)$ and the lowest $\mathrm{OC}$ and $\mathrm{tN}$ was found to be under agricultural land $(0.435 \%, 0.014 \%)$ (Table 2$)$. This is comparable with other similar studies elsewhere (Pereira et al., 2013; Gol, 2009 and Iqbal et al., 2014). The study indicates the degradation of natural forest and conversion to agricultural land was significantly decreased soil $\mathrm{OC}$ and $\mathrm{tN}$. The regular addition of plant litter (above and below ground plant parts) and limited disturbances in the natural forest (grazing, logging, lack of tillage, high plant biodiversity, and root exudates) (Iqbal and Goni, 2015 and Srivatava and Singh 1991) may contribute for high soil organic carbon concentration. Moreover, the higher soil OC and $\mathrm{tN}$ in bamboo plantation as compared to degraded forest and agricultural land was probably due to addition of nutrient rich leaf litter to soil and also due to recycling of these nutrients (Chaudhary et al., 2008 and Behera et al., 2010: Jenkinson and Rayner (1977); Paul et al., (1997); Tripathi and Singh (2007); Saha et al., 2010; Vesterdal and Leifeld, 2010; Tripathi and Singh, 2007 and Singh and Ghoshal, 2006).

Microbial biomass is considered a sensitive indicator of soil quality and is closely related to soil fertility. In this study, the MBC and MBN were significantly affected by land use changes. It was observed that the $\mathrm{MBC}$ and $\mathrm{MBN}$ in natural forest were found to be higher and significantly decreased in degraded forest and agricultural land (Table 2). This result is consistent with the observations of other studies ((Kara and Botal, 2008 and Pabst et al., 2013). The highest MBC and MBN in the natural forest is likely the result of increased supply of soil organic matter, more diverse organic matter input and associated processes. For example, previous studies have demonstrated that mixed forests exhibited higher quality of litter production and higher rate of litter decomposition and soil nutrient mineralization than monocultures. High levels of root 
debris and exudates supported high microbial activity (Kara and Botal, 2008; Bhuyanet al., 2013).

The metabolic activities of soil microbial communities under four different land use types was quantified by measuring the amount of $\mathrm{CO}_{2}$ produced or $\mathrm{O}_{2}$ consumed in a given soil (Table 2). The study found that natural forest was higher in soil BR while agricultural land was recorded the least. Natural forest and bamboo planation were significantly different from degraded forest and agricultural land. The similarity of the soil basal respiration values in the different areas suggested similar microbial activity (Pereira et al., 2013). The higher basal soil respiration in the natural forest indicates the higher soil microbial activity due to the permanent and continuous addition of source of labile organic matter to the soil and the consequent stimulation of heterotrophic microorganisms; rapid decomposition of organic residues that make nutrients available for plant growth (Araújo et al., 2009; Pereira et al., 2013). Soil BR in bamboo plantation was $2 \%$ lower than natural forest, but $5 \%$ and $6 \%$ higher than degraded forest and agricultural land, respectively. Such arise in soil basal respiration showed the trend of restoration of degraded forest towards the natural forest occurring with bamboo plantation.

The present study revealed that change in land use significantly affects the b-glucosidase activity. From Table 2, it can be seen that the b-glucosidase activity in the natural forest is quite higher than other land use types. This is consistent with previous studies (Bandick and Dick, 1999; Roldan et al., (2005). The higher b-glucosidase activities in natural forest may be the consequence of both microbial growth and stimulation of microbial activity by enhanced resource availability (increase in the input of organic matter in the soil and improvement of soil physical properties ), as well as of changes in microbial community composition (Bhattacharya et al., 2005; Eivazi and Tabatabai, 1990; Iovieno et al., 2009; Tejada et al., 2009; Mandal et al., 2007 and Nayak et al., 2007; Kong et al., 2007; Liu et al., 2008). Compared to natural forest the b-glucosidase activity in bamboo planation was $10 \%$ lower; while $9 \%$ and $4 \%$ higher than degraded forest and agricultural land, respectively. It was significant at $p<0.05$. The increment of enzyme activity in bamboo plantation as compared to degraded forest and agricultural land may be due to addition of leaf litter from bamboo, which leads to stimulate microbial metabolism and decomposition rate (Masciandaro et al., 2003). Unlikely, the b-glucosidase activity was deceased as compared to natural forest may be due to the thinner canopy and greater soil exposure may have resulted in greater temperature and soil moisture fluctuation, as well as of other factors that influence the decrease microbial activity (Pereira et al., 2013).

According to Oyedele et al., (2015) microbial biomass carbon and microbial biomass nitrogen were significantly correlated to the physico-chemical properties of the soil. The same result was found in the present study (Table 3). On average $95 \%$ of the microbial biomass and activities were governed by the soil organic carbon, soil total nitrogen, water holding capacity, soil aggregates, porosity and bulk density either positively or negatively (Table 4). The significant positive relations between the soil $\mathrm{MBC}$ and SOC agree with earlier reports by (Logahet al., 2010; Yang et al., 2010; Makova et al., 2011; Cheng et al., 2013; Bhuyanet al., 2013). This 
might be due to microbial biomass concentration depended on the organic matter availability to microbial activity (Anderson \&Domsch, 1989), however, Insam \& Domsch (1989) found no correlation between the biomass carbon and organic carbon. Similarly, SOC was significantly correlated to STN (Yang et al., 2010; Cheng et al., 2013; Kara and Bolat, 2007) while STN was strongly related to MBN agrees with results by (Yang et al., 2010). These results indicate that MBN levels in the soils were determined by SOC and STN (Adeboye et al., 2011). Several studies have found strong correlations between MBN and STN (Anderson and Domsch, 1989; Insam et al., 1989).

Furthermore, the significant positive relations between the soil MBC and MBN agree with earlier reports by (Li et al., 2013; Kara and Bolat, 2007). As mentioned above, soil organic carbon significantly positively correlated with soil total nitrogen; soil organic $\mathrm{C}$ increases, the total $\mathrm{N}$ increase and vice versa. The dynamics of $\mathrm{N}$ in mineral soil is closely linked to $\mathrm{C}$, because most $\mathrm{N}$ exists in organic compounds and heterotrophic microbial biomass, which utilize organic $\mathrm{C}$ for energy. As a result, the microbial biomass $\mathrm{N}$ showed a significant positive correlation with microbial biomass $\mathrm{C}$. On the other hand, significant positive correlations between microbial biomass carbon, soil basal respiration and microbial biomass nitrogen indicate that the dynamics of these three elements are closely interlinked in the nutrients poor tropical soils (Arunachalam, 2003).

The results of the present study showed that natural forest was highest in microbial diversity (PLFAs) than bamboo plantation, degraded forest and agricultural land. The results of the present investigation were corroborates with the many previous research reports (Torsvik and Ovreas, 2002; Mishra, 1996). The study revealed that there were higher PLFAs from $\mathrm{G}^{+}$bacteria along the land use types than $\mathrm{G}^{-}$and fungal PLFAs. The better $\mathrm{G}^{+}$adaptability to various environmental stresses relative to their $\mathrm{G}^{-}$counterparts is attributed to their ability to form spores, which promote survival under conditions of carbon (C) limitation (Boylen and Ensign,1970), and possibly facilitates growth of the former over the latter (Moore-Kucera and Dick, 2008). Among the bacterial PLFAs, $\mathrm{G}^{-}$PLFAs appeared to be more prone to disturbance. The decrease in the fungal community in degraded forest could be because filamentous fungi are more sensitive to physical disturbance than single celled organisms (Kabir et al., 1999). In agricultural land, physical disturbance, mainly tillage, destroyed fungal mycelium networks, and the combination of mechanical destruction, soil compaction, and reduced pore volume collectively led to the lowest fungal PLFA values (Bardgett et al., 2001; Garcia-Orenes et al., 2013). This might be due to changes in litter quantity and quality, which possibly accounts for the changes in bacterial and fungal PLFAs (Denef et al., 2009).

Soil physico-chemical and biological properties were significantly affected by land use change. Water holding capacity, porosity, soil macro-aggregates, soil organic carbon, and soil total nitrogen were found to be higher in natural forest followed by in decreasing order bamboo plantation, degraded forest and agricultural land. In contrast to this, agricultural land was higher in bulk density as compared with other land use types whereas natural forest was lower in bulk 
density. Soil organic carbon, soil total nitrogen, moisture content, porosity, water holding capacity, soil macro aggregates were positively correlated to each other and negatively correlated with bulk density, meso and micro soil aggregates. Among the four land use type's natural forest had high microbial diversity followed by in decreasing order bamboo planation, degraded forest and agricultural land. Thus bamboo based fallow has the potential for improving soil quality in the short term.

\section{Methods}

\section{Study area and Description of sites}

The study was conducted in Baranas Hindu University, Varanasi, India from March to August, 2016. Samples were collected from Barkachha, Mirzapur district. Mirzapur is located at $25.15^{\circ}$ $\mathrm{N} 82.58^{\circ}$ E. It has an average elevation of 80 meters (265 feet). It is a city in Uttar Pradesh, India, roughly $650 \mathrm{~km}$ from both Delhi and Kolkata, almost $89 \mathrm{~km}$ from Allahabad and $57 \mathrm{~km}$ from Varanasi. It has a population of 233,691 (2011 census). The climate in Mirzapur is warm and temperate. In winter, there is much less rainfall than in summer. The average annual temperature and rainfall is $26^{\circ} \mathrm{C}$ and $975 \mathrm{~mm}$, respectively. The study area was classified into four sites based on their vegetation cover: Natural forest, Degraded forest, Bamboo plantation and agricultural land (Fig 1).

The forest site was the mixed dry deciduous type dominated by Acacia catechu Wild., Albiziaodoratissima Benth., Acacia nilotica (L.) Willd. Boswelliaserrata Roxb., Nyctanthesarbortristis L., with scattered trees of AzadirachtaindicaJuss. And ZizyphusglaberrimaSantap. The forest floor was covered with herbaceous vegetation comprising Ocimumamericanum L., Pisumarvense L., Rhynchosia minima (L.) DC., Cassia sophera(L.) Roxb.,Acrocephalusindicus (Burm. f.) Kuntze.,Cynodondactylon L., and Oplismenusburmannii Ritz. The degraded forest site was dominated by $Z$. glaberrima, ChrysopogonfulvusSpreng.,Heteropogoncontortus L.,Adina cordifoliaRoxb. and scattered trees of ButeamonospermaLamk. Herbaceous vegetation in the degraded forest was dominated by Cassia tora L.,Oldenlandiadiffusa Roxb., Sporobolus spp., Panicumpsilopodium Trin. and Alysicarpusvarginalis (L.) DC.

\section{Soil Sampling and Techniques}

Soil sample was taken from four land use types (NF, DF, BP and AL). The natural forest was further divided into six sub-sites of $100 \mathrm{~m}$ x $100 \mathrm{~m}$. From each sub-site, four soil samples were collected (i.e. 24 soil samples in total from each study site) and mixed to represent the single composite sample of a study site. The same procedure was followed for degraded forest, bamboo plantation and agricultural land. The samples were collected from $15 \mathrm{~cm}$ depth by using core borer. Then the sampled soil was immediately brought to the laboratory by (approx. 250g) in clean, dry and sterile polythene bags using sterilized spatula. The soil physico-chemical 
characteristics (moisture, $\mathrm{pH}$ and organic content) were analyzed by standard methods as suggested by (Allen et al., 1974 and Waksman 1952).

\section{Soil analysis}

Soil physico-chemical characteristics; moisture, Bulk density/particle density, Porosity, Soil water holding capacity (WHC), Soil aggregates, $\mathrm{pH}$ and organic content were analyzed by standard methods as suggested by (Allen et al., 1974; Waksman, 1952; Kemper and Chepil, 1965).

\section{Soil organic carbon and total nitrogen}

Soil organic $\mathrm{C}$ was estimated by the dichromate oxidation and titration method (Kalembasa and Jenkinson, 1973), whereas total $\mathrm{N}$ concentration was measured by the micro kjeldahl method (Jackson, 1973) by using a Gerhardt digester and distillation unit. The calculation was done by the following formulas:

$$
\begin{gathered}
\% \text { Organic carbon }=\frac{(B-T) * 0.15}{\text { Sample weight }(g)} \\
\% N=\frac{(T-B) * 0.1 * 1.4}{x \text { sample }}
\end{gathered}
$$

\section{Whereas, B-blank titrate value; T-soil titrate value}

\section{Soil Microbial Biomass}

Microbial biomass $\mathrm{C}$ was estimated by the chloroform fumigation extraction method using purified $\mathrm{CHCl}_{3}$ treatment (Brookes et al., 1985; Vance et al., 1987). Microbial biomass $\mathrm{N}$ concentration was measured by the micro kjeldahl method (Jackson, 1973) by using a Gerhardt digester and distillation unit. Microbial biomass carbon ( $\mu \mathrm{g}$ dry soil) and $\mathrm{N}$ are calculated by the following formulas:

Microbial Biomass $C=\frac{N F-F}{B} * 3168$ and

Microbial Biomass $N=(F u-N F u) * 207.407$

\section{Basal Respiration}

The basal respiration/metabolic activities of soil microbial community were determined by (Namipieriet al 1990) method.

Calculation: $\mu \mathrm{g} \mathrm{CO}_{2}$ oven dry soil $/ \mathrm{h}$ at $22^{\mathrm{O}} \mathrm{C}=\underline{(\mathrm{Vo}-\mathrm{V}) * \mathrm{~S} * 22 * 12 * 1000}$

$\mathrm{M} * \mathrm{dwt} * \mathrm{t} * 44$ 


$$
\mu \mathrm{g} \text { oven dry soil }=\frac{\left(V_{o}-V\right) * S * 22 * 12 * 1000}{M * D W t . t * 44}
$$

Whereas; Vo- volume of $\mathrm{HCl}$ used for titration of blank (mean of three replicates); V-Volume of $\mathrm{HCl}$ used for titration of sample (mean of three replicates); $\mathrm{S}$ - the strength of the $\mathrm{HCl}$ in normality; M- weight of soil g/sample; dwt- the oven dry weight of $1 \mathrm{~g}$ sample; $\mathrm{t}$ - time of incubation in hrs.

\section{Soil Enzyme}

$\beta$-Glucosidase activity was assayed by the method of Eivazi and Tabatabai (1988), using the substrate analogue para-nitrophenyl- $\beta$-d-glucopyranoside (pNPG). The activity of the enzyme is calculated by the following formula:

$$
E A=\frac{O D}{C F} * 100+\frac{n(n-1) x^{2}}{2}
$$

\section{Soil microbial community analysis}

To analysis soil microbial community phospholipid fatty acid assay (PLFAs) were used. The PLFAs includes extraction, fractionation, methylation and chromatography. Phospholipid fatty acids was extracted and quantified from $3 \mathrm{~g}$ (dry weight equivalent) of soils using a procedure described by Bossio et al., (1998).

\section{Declarations}

Ethics approval and consent to participate

Not applicable

\section{Consent for publication}

Not applicable

\section{Availability of data and materials}

The datasets used and/or analysed during the current study are available from the corresponding author on reasonable request.

\section{Competing interests}

The authors declare that they have no competing interests.

\section{Funding}

The study was funded by NAM S\&T Centre Research Training Fellowship for Developing Country Scientists (RTF-DCS) for six months in 2016. The NAM S \& T Centre has covered the cost of the chemicals, monthly salary of WG for six months and one round air ticket from Ethiopia to India. The role of the center was following the overall research activity like financial management, managing report from the researcher and managing field visit of the researcher. 


\section{Authors' Contributions}

WG and NG have played a great role for the successfulness of the paper. WG and NG have involved in study designing and sample site selection, conducting laboratory experiment, data analysis, and interpretation of the analyzed data and review different article for writing up the paper.

\section{Acknowledgements}

We are greatly indebted to the NAM S\&T Centre of India for providing us with all the necessary financial support to undertake the. We would like to extend our gratitude to the Department of Botany, Banaras Hindu University, India for their generous support at different stages of the study period. The authors also would like to thank anonymous reviewers for their valuable comments.

\section{References}

Adeboye MKA, Bala A, Osunde AO, Uzoma AO, Odofin AJ and Lawal BA (2011). Assessment of soil quality using soil organic carbon and total nitrogen and microbial properties in tropical agroecosystems. Agricultural Sciences, 2: 34-40.

Allen SE, Grimshaw HM, Parkinson JA and Quarmby C (1974).Chemical analysis of ecological materials. Blackwell Scientific publications, Oxford.

Anderson TH and Domsch KH(1989). Ratio of microbial biomass carbon to total organic carbon in arable soils.Australian Journal of Soil Research, 30, 195-207.

Anderson TM and Domsch KH (1989).Ratios of microbial biomass carbon to total organic carbon in arable soils.Soil Biol. Biochem. 25: 393-395.

Araújo ASF, Leite LFC, Santos VB and Carneiro RFV (2009).Soil Microbial Activity in Conventional and OrganicAgricultural Systems. Sustainability, 1:268-276.

Bandick AK and Dick RP (1999). Field management effects on soil enzymes activities. Soil Biology \& Biochemistry, 31:1471-1479.

Bardgett R D, Jones A C, Jones D L, Kemmitt S J, Cook R, Hobbs P J. 2001. Soil microbial community patterns related to the history and intensity of grazing in sub-montane ecosystems. Soil Biol Biochem. 33: 1653-1664.

Bhattacharya P, Chakrabarti K and Chakraborti A (2005). Microbial biomass and enzyme activities in submerged rice soil amended with municipal solid waste compost and decomposed cow manure. Chemosphere, 60:310-318.

Bhuyan SI, Tripathi OP and Khan ML (2013). Seasonal changes in soil microbial biomass under differentagro-ecosystems of Arunachal pradesh, North East India. The Journal of Agricultural Sciences, 8:142-152.

Bossio DA, Scow KM, Gunapala N, Graham KJ (1998). Determinants of Soil Microbial Communities: Effects of Agricultural Management, Season, and Soil Type on Phospholipid Fatty Acid Profiles. MicrobEcol, 36:1-12. 
Bot A and Benites J (2005).The importance of soil organic matter: Key to drought-resistant soil and sustained food production. VialedelleTerme di Caracalla, 00100 Rome, Italy.

Brookes P.C. 1995.The use of microbial parameters in monitoring soil pollution by heavy metals. Biol. Fertil. Soils 19:269-279.

Brookes, P.C., Landman, A., Pruden, G., Jenkinson, D.S., 1985. Chloroform fumigation and release of soil N: a rapid direct extraction-method to measure microbial biomass nitrogen in soil. Soil Biology \& Biochemistry 17, 837-842.

Chaudhary, D. R., A. Ghose, J. Chikara and J. S. Patolia (2008).Soil characteristics and mineral nutrient in wild Jatropha population of India.Commun. Soil Sci. Plan., 39 : 1476- 1485.

Chen DD , S. H. Zhang, S. K. Dong, X. T. Wang and G. Z. Du (2010). Effect of land use on soil nutrients and microbial biomass of an alpine region on the northeastern Tibetan plateau, China. Land Degrad. Develo., 21 : 446-452.

Cheng F, PengX, Zhao P, Yuan J , Zhong C, Cheng Y, Cui C and Zhang S (2013). Soil Microbial Biomass, Basal Respiration and Enzyme Activity of Main Forest Types in the Qinling Mountains. PLOS ONE, 8:1-12.

Christensen BT (1996). Matching measurable soil organic matter fractions with conceptual pools in simulation models of carbon turnover: revision of model structure. In: Powlson DS, Smith P, Smith JU (ed) Evaluation of soil organic matter models using existing long-term datasets. Global environmental change.Nato ASI series vol 38. Springer, Berlin Heidelberg ,New York, pp 143160.

Diaz E (2004).Bacterial degradation of aromatic pollutants:a paradigm of metabolic versatility. IntMicrobiol7:173 - 180 .

Eivazi F and Tabatabai MA (1988).Glucosidases and galactosidases in soils.Soil Biol. Biochem, 20:601606.

Eivazi F and Tabatabai MA (1990).Factors affecting glucosidase and galactosidase activities in soils.Soil Biology \& Biochemistry, 22:891-897.

Fierer N (2008). Microbial biogeography: patterns in microbial diversity across space and time. In: Accessing Uncultivated Microorganisms: from the Environment toOrganisms and Genomes and Back. K. Zengler (editor). AS M Press, Washington DC pgs.95-115.

Frostegard A and Baath E (1996). The use of phospholipid fatty acid analysis to estimate bacterial and fungal biomass in soil.Biology and Fertility of Soils, 22:59-65.

Garc'1a-Orenes F, Morug'an-Coronado A, Zornoza R, Cerd'a A, Scow K. 2013. Changes in soil microbial community structure influenced by agricultural management practices in a Mediterranean agro-ecosystem. PLoS One. 8: e80522.

GillerKE.,Beare MH., and Lavelle P. (1997). Agricultural intensification, soil biodiversity and agroecosystem function. Appl Soil Ecol; 6: 3-16.

Gol, C. (2009). The effects of land use change on soil properties and organic carbon at Dagdami river catchment in Turkey. J. Environ. Biol., $30: 825-830$. 
Gu Y., Zhang X., and Tu S. (2009). Soil microbial biomass, crop yields, and bacterial community structure as affected by long-term fertilizer treatments under wheat-rice cropping. Eur J Soil Biol;45: 239-46.

Gupta RD, Arora S, Gupta GD and Sumberia NM (2010).Soil physical variability in relation to soil erodibility under different land uses in foothills of Siwaliks in N-W India. Tropical Ecology, 51(2): 183-197.

Harpole W (2010). Neutral theory of species diversity.Nature Education Knowledge.1: 31.

Insam H, Parkinson D and Domsch KH (1989). Influence of macroclimate in soil microbial biomass. SoilBiology and Biochemistry, 21, 211-221.

Insam HD and Domsch KH (1989). Influence of microclimate on soil microbial biomass. Soil Biol. Biochem, 21: 211-21.

Iovieno P, Morra L, Leone A, Pagano L and Alfani A (2009).Effect of organic and mineral fertilizers on soil respiration and enzyme activities of two Mediterranean horticultural soils.Biology and Fertility of Soils, 45: 555-561.

Iqbal AM, Hossen SM and IslamNM(2014).Soil organic carbon dynamics for different land uses andsoil management practices in Mymensingh Proceedings of 5th International Conference on Environmental Aspects of Bangladesh.

Jackson ML (1973). Soil Chemical Analysis. Prentice-Hall of India Limited, New Delhi, 574pp.

Jenkinson DS and RaynerJII (1997).The turnover of soil organic matter in some of the rothamsted classical experiments.Soil Science, 123: 298-305.

Jenkinson DSand Ladd JN(1981). Microbialbiomass in soil: measurement and turnover. SoilBiochem.5: 415-417.

Jordan D, Kremer RJ, Bergfield WA, Kim KY and Cacnio VN (1995).Evaluation of microbial methods as potential indicators of soil quality in historical agricultural fields.Biol. Fertil. Soils, 19:297-302.

Kabir Z, O'Halloran I P, Hamel C. 1999. Combined effects of soil disturbance and fallowing on plant and fungal components of mycorrhizal corn (Zea mays L.). Soil Biol Biochem. 31: 307-314.

Kalembasa, S.J., Jenkinson, D.S., 1973. A comparative study of titrimetric and gravimetric methods for the determination of organic carbon in soil. Journal of Scientific Food Agriculture 24, 10851090 .

Kara O and Bolat L (2008). The Effect of Different Land Uses on Soil Microbial Biomass Carbon and Nitrogen in Bartin Province. Turk J Agric For, 32:281-288.

Kaschuk G., Alberton O., and Hungria M. (2011).Quantifying effects of different agricultural land uses on soil microbial biomass and activity in Brazilian biomes: inferences to improve soil quality.Plant Soil; 338: 467-81.

Kemper, W.D., and W.S. Chepil. 1965. Size distribution of aggregates. p. 499- 509.In C.A. Black (ed.) Methods of soil analysis.Part I. Agron.Monogr.No. 9.ASA, SSSA, Madison, WI. 
Kirk J, Beaudette L, Hart M, Moutoglis P, Klironomos J, Lee H, and Trevors J (2004). Methods of studying soil microbial diversity. J Microbiological Methods; 58:169- 188.

Kong CH, Zhao H, Xu XH, Wang P and Gu Y (2007): Activity and allelopathy of soil of flavone oglycosides from rice. Journal of Agricultural and Food Chemistry, 55: 6007-6012.

Kummerer K(2004). Resistance in the environment.J AntimicrobChemoth.45: 311 - 320.

Li W, Yang G, Chen H, Tian J, Zhang Y, Zhu Q, Peng C and Yang J (2013). Soil available nitrogen, dissolved organic carbon and microbial biomass content along altitudinal gradient of the eastern slope of Gongga Mountain. Ecological Society of China.Elsevier, 33:266-271.

Liu W, Lu HH, Wu WX, Wei QK, Chen YX andThies JE (2008). Transgenic Bt rice does not affect enzyme activities and microbial composition in the rhizosphere during crop development. Soil Biology and Biochemistry, 40:475-486.

Logah V, Safo EY, Quansah C and Danso I (2010). Soil Microbial Biomass Carbon, Nitrogen and Phosphorus Dynamics under Different Amendments and Cropping Systems in the Semideciduous Forest Zone of Ghana. West African Journal of Applied Ecology, 17:121-133.

Makova J, Javorekova S, Medo J and MajerčíkovaK (2011). Characteristics of microbial biomass carbon andrespiration activities in arable soil and pasturegrassland soil. Journal of Central European Agriculture, 12:752-765.

Mandal A., Patra A.K., Singh D., Swarup A., Masto R.E. (2007): Effect of long-term application of manure and fertilizer on biological and biochemical activities in soil during crop development stages. Bioresource Technology, 98: 3585-3592.

Masciandaro G, Ceccanti B, Benedicto S, Lee HC and Cook HF (2003). Enzyme activity and C and N pools in soil following application of mulches.Can. J. Soil Sci.84:19-30.

Moore J C, de Ruiter P C. 1991. Temporal and spatial heterogeneity of trophic interactions within belowground food webs. Agric Ecosyst Environ. 34: 371-397.

Nayak DR., Babu YJ and Adhya TK(2007). Long-term application of compost influences microbial biomass and enzyme activities in a tropical AericEndoaquept planted to rice under flooded condition. Soil Biology and Biochemistry, 39:1897-1906.

Ndour NYB, Achouak W and Christen R (2008). Characteristics of microbial habitats in a tropical soil subject to different fallow management. Appl Environ Microbiol; 38:51-61.

Oyedele AO, Olayungbo AA, Denton OA, Ogunrewo OM and Momodu FO (2015).Assessment of the microbial biomass carbon, nitrogen and phosphorus in relation to physico-chemicalproperties of AcricLuvisols in Ibadan South West.Nigeria Journal of Agriculture and Environment for International Development, 109:179-187.

Pabst H, Kühnel A and KuzyakovaY (2013). Effect of land-use and elevation on microbial biomass and water extractable carbon in soils of Mt. Kilimanjaro ecosystems.Applied Soil Ecology, Elsevier, 67:10-19.

Paul, E. A., K. Paustian, E. T. Elliott and C. V. Cole (1997).Soil organic matter in temperate agro ecosystems. CRC Press, New York. 
PeixotoRS.,Coutinho HLC., and Madari B. (2006). Soil aggregation and bacterial community structure as affected by tillage and cover cropping in the Brazilian Cerrados. Soil Till Res; 90:16-28.

Pereira JDM, Baretta D, Bini D, Vasconcellos RF \& Cardoso EJBN (2013). Relationships between microbial activity and soil physical and chemical properties in native and reforested Araucaria Angustifolia forests in the state of São paulo, Brazil. R. Bras. Ci. Solo,37:572-586.

REEMA GONI, NAMRATA SHARMA, SHEIKH IQBAL S. C. TIWARI (2015). Soil organic carbon pool under different land uses in AchanakmarAmarkantak Biosphere Reserve of Chhattisgarh, India.Current science, 110:771-773.

Roldán A, Salinas-García JR, Alguacil MM, Díaz E and Caravaca F (2005). Soil enzyme activities suggest advantages of conservation tillage practices in sorghum cultivation under subtropical conditions. Geoderma, 129:178-185.

S.E. Allen, H.M. Grimshaw, A.P. Rowland, Chemical analysis, in: P.D. Moore, S.B. Chapman (Eds.), Methods in Plant Ecology, Blackwell, Oxford, 1986, pp. 285-344.

Saha, S. K., P. K. R. Nair, V. D. Nair and B. M. Kumar (2010).Carbon storage in relation to soil size fractions under tropical tree-based land-use systems. Plant Soil, 328 : 433-446.

Sharma P., Rai S.C., Sharma R., Sharma E., 2004. Effects of land-use change on soil microbial C, $\mathrm{N}$ and $\mathrm{P}$ in a Himalayan watershed. Pedobiologia, vol. 48:83-92.

Silva A., Babujiaa L., Matsumotoa L., Guimarãesb M., and Hungria M. (2013).Bacterial Diversity under Different Tillage and Crop Rotation Systems in an Oxisol of Southern Brazil.J Open Agri;7: 4047.

Singh J.S., Raghubanshi A.S., Singh R.S., Srivastava S.C. (1989): Microbial biomass acts as a source of plant nutrients in dry tropical forest and savanna. Nature, 338: 499-500.

Singh JS, Singh DP and Kashyap AK (2009).Comparative account of the microbial biomass-N and Nmineralization of soils under natural forest, grassland and crop field from dry tropical region, India.Plant Soil Environ, 55:223-230.

Singh MK and Ghoshal N. (2011). Impact of land use change on soil organic carbon content in dry tropics. Plant Archive, 11: 903-906

Singh, S. and N. Ghoshal (2006).Effect of cultivation on major physical and chemical properties of soil. Plant Archives, 6 : 611-613.

Srivastava S.C., Singh J.S. (1991): Microbial C, N and P in dry tropical forest soils: effects of alternate land uses and nutrient flux. Soil Biology and Biochemistry, 23: 117-124.

Tejada M., Hernandez M.T., Garcia C. (2009): Soil restoration using composted plant residues: Effects on soil properties. Soil and Tillage Research, 102: 109-117.

Torsvik, V.; Ovreas, L. Microbial diversity and function in soil: from genes to ecosystems. Curr. Opin Microbiol. 5, (2002), 240245. [26] Mishra, R.R. Influence of soil environments and surface vegetation on soil microflora. Proc. Nat. Acad. Sci. (India). 26, (1996), 117-123. 
Trasar-Capeda C., Leiros C., Gil-sotres F. and Seoane S. 1998. Towards a biochemical quality index for soils: an expression relating several biological and biochemical properties. Biol. Fertil. Soils 26:100-106.

Tripathi, N. and Singh RS (2009). Influence of different land uses on soil nitrogen transformations after conversion from an Indian dry tropical forest. Catena, 77: 216-223.

Vance ED, Brookes PC, Jenkinson DS (1987) An extraction method for measuring soil microbial biomass C. Soil Biol Bio-chem 19: 703-707.

Vance, E.D., Brookes, P.C., Jenkinson, D.S., 1987. An extraction method for measuring soil microbial biomass carbon. Soil Biology \& Biochemistry 19, 703-707.

Waksman SA (1952). Soil Microbiology, Jhon-Wiley and Sons, New York.

White, D.C., Davis, W.M., Nickels, J.S., King, J.D., Bobbie, R.J., 1979. Determination of the sedimentary microbial biomass by extractible lipid phosphate. Oecologia 40, 51-62.

Xiangmin F, Qingli W, Wangming Z, Wei Z, Yawei W, Lijun N, Limin D (2014). Land Use Effects on Soil Organic Carbon, Microbial Biomass and Microbial Activity in Changbai Mountains of Northeast China, Chin. Geogra. Sci.24 :297-306.

Yang K, Zhu J, Zhang M, Yan Q and Sun OJ (2010). Soil microbial biomass carbon and nitrogen in forest ecosystems of Northeast China: a comparison between natural secondary forest and larch plantation. Journal of Plant Ecology, 3:175-182.

Yin C., Jones KL., Peterson DE. (2010). Members of soil bacterial communities sensitive to tillage and crop rotation.Soil BiolBiochem; 42: 2111-8.

Zhang H., Thompson M.L., Sandor J.A. (1988): Compositional differences in organic matter among cultivated and uncultivated Argiudolls and Hapludalfs derived from loess. Soil Science Society of America Journal, 52: 216-222.

Zhou JZ., Xia BC., Treves DS., (2002). Spatial and resource factors influencing high microbial diversity in soil.Appl Environ Microbiol; 68:326-34.

Qian Zhang, Junjun Wu, Fan Yang, Yao Lei1, Quanfa Zhang \& Xiaoli Cheng (2016). Alterations in soil microbial community composition and biomass following agricultural land use change. Nature Scientific reports.

\section{Figure Legends}



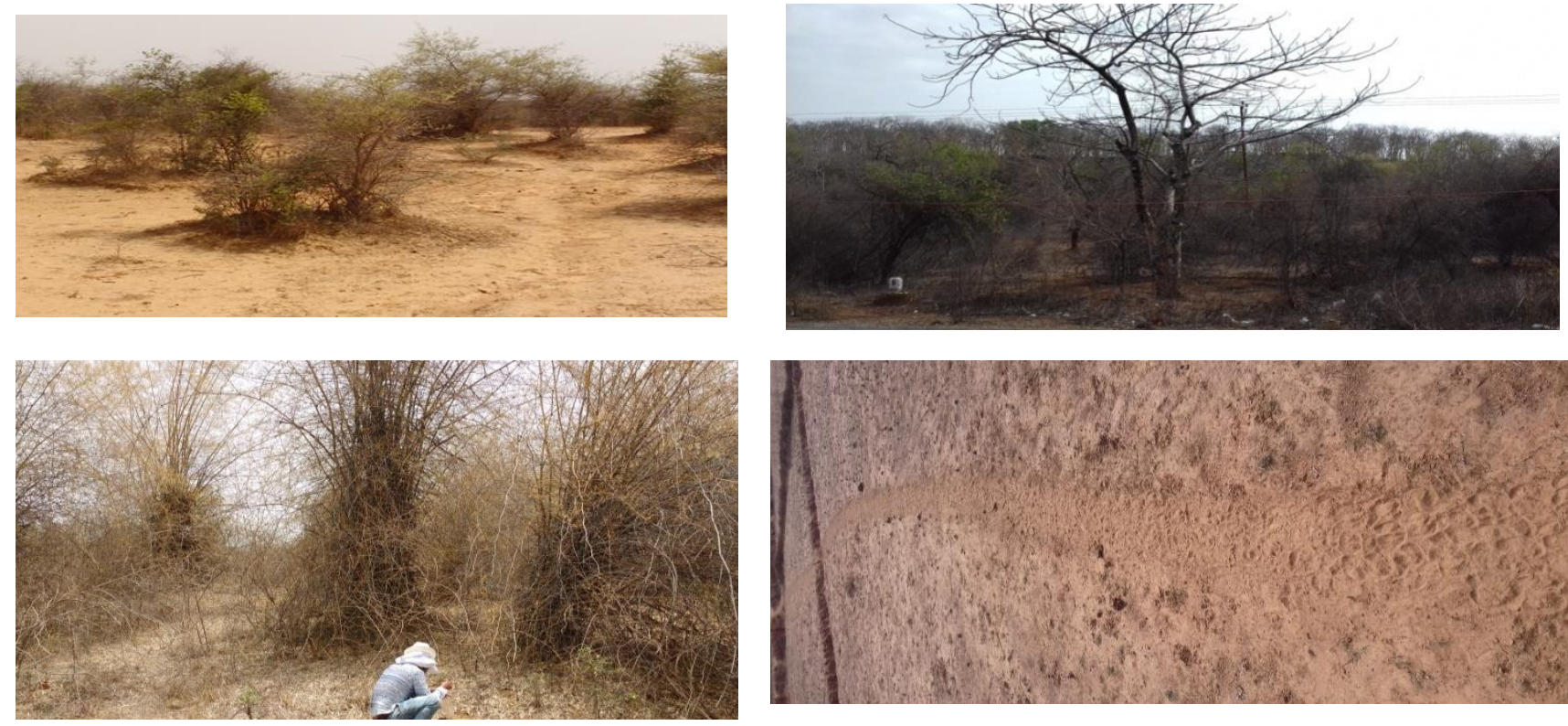

572 Figure 1. Study sites: Natural forest (NF), Degraded forest (DF), Bamboo plantation (BP) and 573 Agricultural land (AL), respectively.

A

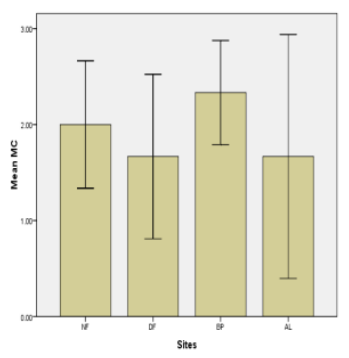

B

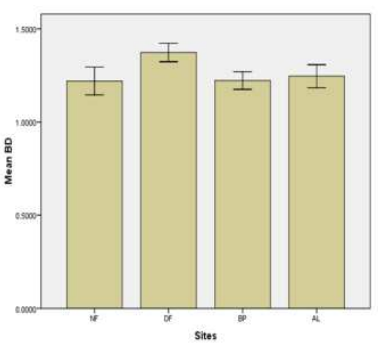

C

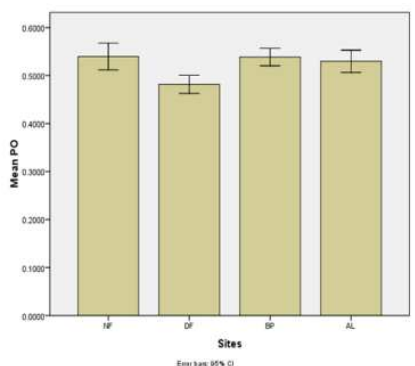

D

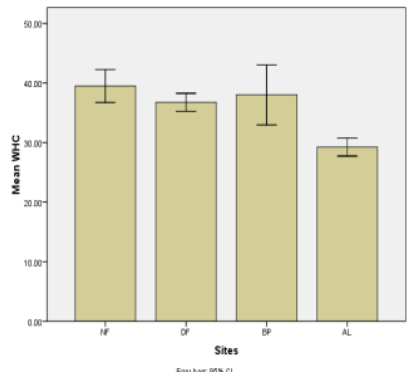

574

575

\begin{tabular}{lccccc}
\hline & \multicolumn{4}{c}{ Land use type } & LSD \\
\cline { 2 - 6 } Soil aggregates (\%) & $\mathrm{NF}$ & $\mathrm{DF}$ & $\mathrm{BP}$ & $\mathrm{AL}$ & \\
Macro-aggregates & $64.16 \pm 2.64^{\mathrm{a}}$ & $46.83 \pm 1.00^{\mathrm{b}}$ & $51.65 \pm 5.4^{\mathrm{b}}$ & $42.94 \pm 1.11^{\mathrm{b}}$ & 8.48 \\
Meso aggregates & $25.68 \pm 2.48^{\mathrm{a}}$ & $35.16 \pm 0.73^{\mathrm{b}}$ & $33.10 \pm 4.74^{\mathrm{b}}$ & $36.39 \pm 1.69^{\mathrm{b}}$ & 9.28 \\
\hline Micro-aggregates & $10.16 \pm 1.38^{\mathrm{a}}$ & $18.01 \pm 0.96^{\mathrm{b}}$ & $15.25 \pm 1.86^{\mathrm{ba}}$ & $20.66 \pm 1.81^{\mathrm{b}}$ & 4.65 \\
\hline
\end{tabular}

Figure 2. Comparison of MC, BD, porosity and WHC under different land use types: Natural Forest (NF), Degraded Forest (DF), Bamboo Plantation (BP) and agricultural Land (AL)

Table 1. Percentage of distribution of different dry aggregate soil size classes in different land use types

580 different from each other $(P<0.05)$. 
581 Table 2. Soil organic carbon (SOC), soil total nitrogen (STN), Microbial biomass carbon (MBC),

582 Microbial biomass nitrogen $(\mathrm{MBN})$ and soil basal respiration (SBR) under different land use

583 types.

\begin{tabular}{|c|c|c|c|c|c|c|c|c|c|c|c|c|}
\hline \multicolumn{10}{|c|}{ Land use type } & \multicolumn{2}{|c|}{ LSD } & \\
\hline & \multicolumn{2}{|r|}{ NF } & \multicolumn{2}{|r|}{$\mathrm{DF}$} & \multicolumn{3}{|c|}{$\mathrm{BP}$} & \multicolumn{2}{|c|}{$\mathrm{AL}$} & & & \\
\hline SOC (\%) & \multicolumn{2}{|c|}{$0.84 \pm 0.054^{\mathrm{a}}$} & \multicolumn{2}{|c|}{$0.448 \pm 0.113^{\mathrm{b}}$} & \multicolumn{3}{|c|}{$0.72 \pm 0.074^{\mathrm{a}}$} & \multicolumn{2}{|c|}{$0.435 \pm 0.042^{b}$} & \multicolumn{2}{|c|}{0.21} & \\
\hline STN (\%) & \multicolumn{2}{|c|}{$0.123 \pm 0.013^{\mathrm{a}}$} & \multicolumn{2}{|c|}{$0.027 \pm 0.003^{b}$} & \multicolumn{3}{|c|}{$0.033 \pm 0.0034^{b}$} & \multicolumn{2}{|c|}{$0.014 \pm 0.0016^{b}$} & \multicolumn{2}{|c|}{0.021} & \\
\hline MBC $(\mu \mathrm{g} / \mathrm{g})$ & \multicolumn{2}{|c|}{$570.65 \pm 35.05^{\mathrm{a}}$} & \multicolumn{2}{|c|}{$233.94 \pm 60.36^{b}$} & \multicolumn{3}{|c|}{$479.03 \pm 21.48^{\mathrm{a}}$} & \multicolumn{2}{|c|}{$225.59 \pm 20.84^{b}$} & \multicolumn{2}{|c|}{114} & \\
\hline MBN $(\mu \mathrm{g} / \mathrm{g})$ & \multicolumn{2}{|c|}{$84.21 \pm 3.186^{\mathrm{a}}$} & \multicolumn{2}{|c|}{$48.95 \pm 2.506^{b}$} & \multicolumn{3}{|c|}{$63.05 \pm 4.281^{\mathrm{c}}$} & \multicolumn{2}{|c|}{$43.14 \pm 1.784^{b}$} & \multicolumn{2}{|c|}{9.23} & \\
\hline MBC/MBN & \multicolumn{2}{|r|}{6.77} & \multicolumn{2}{|r|}{4.78} & \multicolumn{3}{|c|}{7.59} & \multicolumn{2}{|c|}{5.23} & & \\
\hline $\operatorname{SBR}\left(\mu \mathrm{g} \mathrm{CO}_{2}\right)$ & 3.6 & $6 \pm 0.064^{a}$ & & $2.69 \pm 0.11^{b}$ & & $3.37 \pm 0$. & $67^{\mathrm{a}}$ & 2.56 & $\pm 0.11^{\mathrm{b}}$ & 0.29 & & \\
\hline $\begin{array}{l}\text { B-glucosidas } \\
(\mu g \mu g \text { PNP g- } \\
1 \text { dry soil h-1 }\end{array}$ & 809 & $.68 \pm 39.7^{a}$ & 38 & $30.50 \pm 17.02$ & & $577.28 \pm 8$ & $4.39^{\mathrm{b}}$ & 492.88 & $\pm 58.13^{c}$ & 181. & & \\
\hline $\begin{array}{l}\text { Values in } \mathrm{M} \\
\text { among the } \mathrm{m} \\
\text { Table } 3 . \mathrm{Cor} \\
\text { from differe }\end{array}$ & $\begin{array}{l}\text { ean } \pm \\
\text { ean va } \\
\text { elation }\end{array}$ & $\begin{array}{l}\text { SE, across } \\
\text { lues at the } \\
\text { matrix fo } \\
\text { uses. }\end{array}$ & $\begin{array}{l}\text { s the } \\
\text { signi } \\
\text { or phy }\end{array}$ & $\begin{array}{l}\text { ows Differe } \\
\text { icance level } \\
\text { sical, chemi }\end{array}$ & $\begin{array}{l}\text { nt let } \\
P<0 . \\
\text { cal, a }\end{array}$ & $\begin{array}{l}\text { ters }(\mathrm{a}, \mathrm{b} \\
.05 \text {. } \\
\text { nd micro }\end{array}$ & c) $\mathrm{sh}$ & $\mathrm{w}$ that $\mathrm{tl}$ & here is $d$ & of soil & & \\
\hline Soil variable & SBR & SOC & MBC & $\begin{array}{c}\text { B- } \\
\text { glucosidase }\end{array}$ & STN & MBN & MC & PO & WHC & BD & MA & ME \\
\hline SOC & $.997 * *$ & 1 & & & & & & & & & & \\
\hline MBC & $.997 * *$ & $1.000^{* *}$ & 1 & & & & & & & & & \\
\hline$B$-glucosidase & 0.877 & 0.91 & 0.903 & 1 & & & & & & & & \\
\hline STN & 0.815 & 0.828 & 0.811 & 0.901 & 1 & & & & & & & \\
\hline MBN & $.960^{*}$ & $.963^{*}$ & $.955^{*}$ & 0.924 & 0.944 & 1 & & & & & & \\
\hline MC & 0.583 & 0.548 & 0.571 & 0.205 & 0.01 & 0.34 & 1 & & & & & \\
\hline PO & 0.758 & 0.703 & 0.703 & 0.401 & 0.555 & 0.712 & 0.615 & 1 & & & & \\
\hline WHC & 0.808 & 0.76 & 0.756 & 0.499 & 0.66 & 0.789 & 0.547 & $.991 * *$ & 1 & & & \\
\hline BD & -0.776 & -0.722 & -0.722 & -0.423 & -0.568 & -0.727 & -0.624 & $-1.000 * *$ & $-.992^{* *}$ & 1 & & \\
\hline MA & 0.926 & 0.929 & 0.918 & 0.909 & $.970 *$ & $.994 * *$ & 0.251 & 0.703 & 0.787 & -0.717 & 1 & \\
\hline ME & -0.89 & -0.901 & -0.887 & -0.929 & $-.989 *$ & $-.982 *$ & -0.154 & -0.623 & -0.718 & 0.637 & $-.994 * *$ & 1 \\
\hline MI & $-.951 *$ & -0.946 & -0.937 & -0.876 & -0.936 & $-.994 * *$ & -0.35 & -0.778 & -0.848 & 0.79 & $-.993 * *$ & $.973 *$ \\
\hline
\end{tabular}

BD, bulk density; WHC, water holding capacity; SOC, soil organic carbon; STN, total nitrogen;

589 MBC, microbial biomass carbon; SBR, soil basal respiration; MBN, microbial biomass

590 nitrogen;PO, porosity; MA, macro aggregates; ME, meso aggregates; MI, micro aggregates

591 Table 4. The amount of total phospholipid fatty acids (PLFAs), bacterial, Gram-positive

592 bacterial, Gram-negative bacterial, and fungal PLFAs (mg/g DW) under four land uses

\begin{tabular}{ccccc}
\hline & NF & BP & DF & AL \\
\hline G- & $37.43 \pm 2.21^{\mathrm{a}}$ & $22.51 \pm 1.75^{\mathrm{d}}$ & $15.78 \pm 0.85^{\mathrm{b}}$ & $5.29 \pm 0.477^{\mathrm{c}}$ \\
\hline
\end{tabular}




\begin{tabular}{lcccc}
\hline G+ & $15.61 \pm 1.25^{\mathrm{a}}$ & $25.17 \pm 2.02^{\mathrm{c}}$ & $30.64 \pm 0.82^{\mathrm{b}}$ & $39.4 \pm 3.73^{\mathrm{c}}$ \\
Fungi & $20.49 \pm 1.24^{\mathrm{a}}$ & $15.55 \pm 1.14^{\mathrm{c}}$ & $10.96 \pm 0.86^{\mathrm{b}}$ & $8.06 \pm 0.59^{\mathrm{b}}$ \\
Total & 73.55 & 63.23 & 57.38 & 52.75 \\
$\mathbf{G}^{+} / \mathbf{G}^{-}$ & 0.42 & 1.12 & 1.94 & 7.44 \\
F/B & 0.386 & 0.326 & 0.236 & 0.18 \\
\hline
\end{tabular}

593 Different letters in a row meant significant difference at $\mathrm{p}<0.05$ levels. 


\section{Figures}
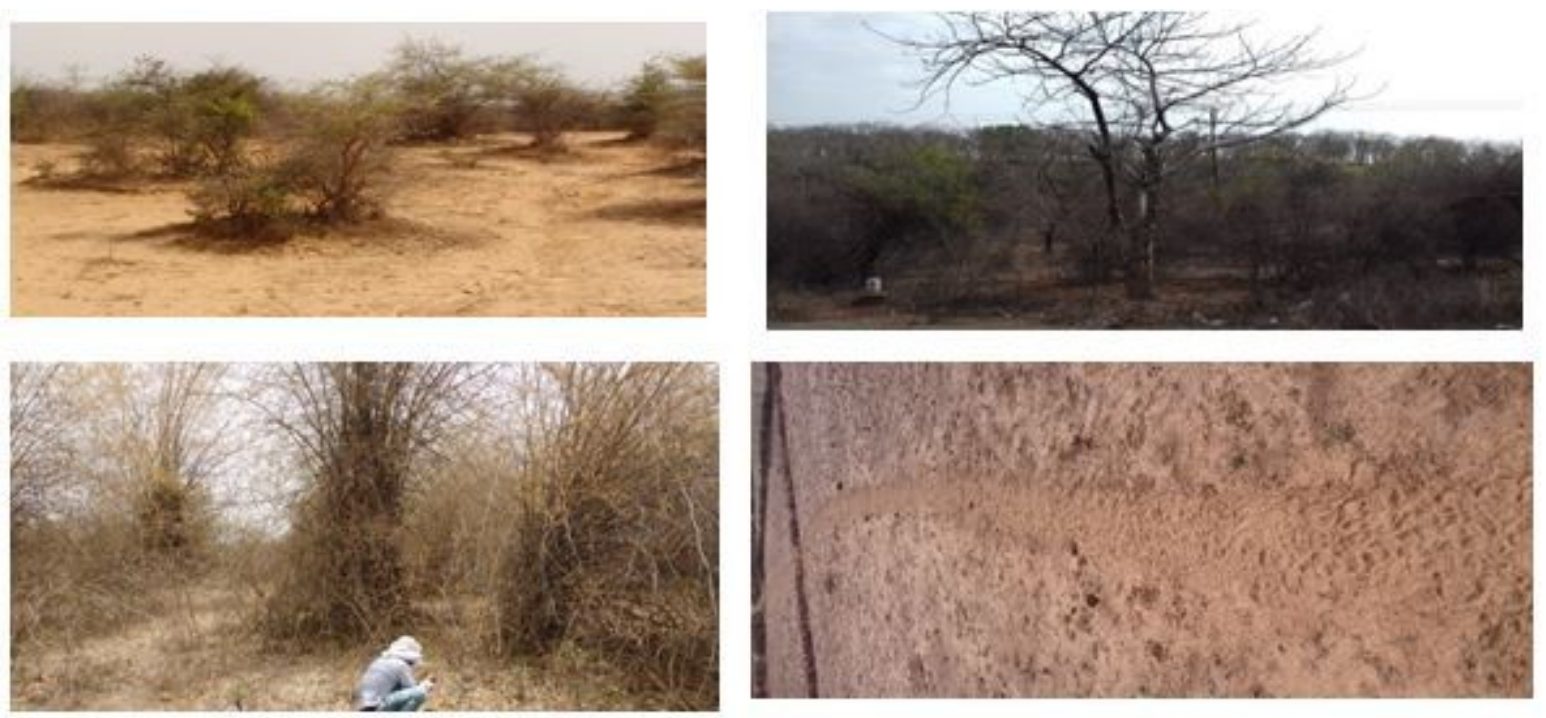

\section{Figure 1}

Study sites: Natural forest (NF), Degraded forest (DF), Bamboo plantation (BP) and Agricultural land (AL), respectively.

A

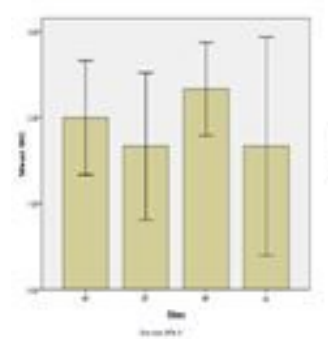

B

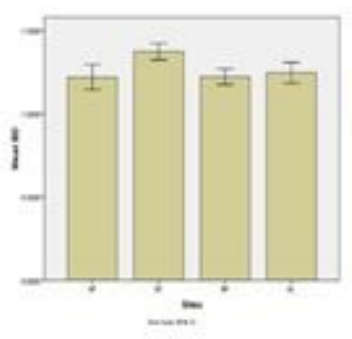

$\mathrm{C}$

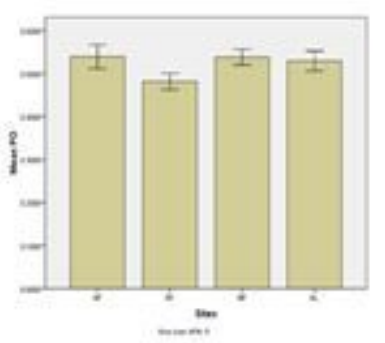

D

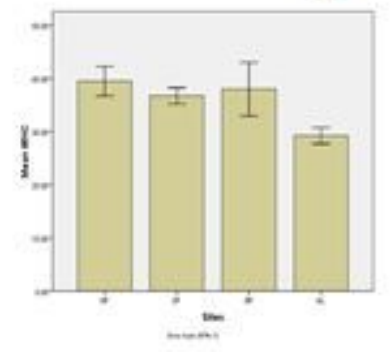

Figure 2

Comparison of MC, BD, porosity and WHC under different land use types: Natural Forest (NF), Degraded Forest (DF), Bamboo Plantation (BP) and agricultural Land (AL) 